\title{
Semi-Quantitative Exposure Assessment of Occupational Exposure to Wood Dust and Nasopharyngeal Cancer Risk
}

\author{
Chatchai Ekpanyaskul ${ }^{1}$, Suleeporn Sangrajrang ${ }^{2 *}$, Wiwat Ekburanawat ${ }^{3}$, Paul \\ Brennan $^{4}$, Andrea Mannetje ${ }^{5}$, Anamai Thetkathuek ${ }^{6}$, Nutjaree Saejiw ${ }^{7}$, Tassanu \\ Ruangsuwan $^{8}$, Paolo Boffetta ${ }^{9}$
}

\begin{abstract}
Occupational exposure to wood dust is one cause of nasopharyngeal cancer (NPC); however, assessing this exposure remains problematic. Therefore, the objective of this study was to develop a semi-quantitative exposure assessment method and then utilize it to evaluate the association between occupational exposure to wood dust and the development of NPC. In addition, variations in risk by histology were examined. A case-control study was conducted with 327 newly diagnosed cases of NPC at the National Cancer Institute and regional cancer centers in Thailand with 1:1 controls matched for age, gender and geographical residence. Occupational information was obtained through personal interviews. The potential probability, frequency and intensity of exposure to wood dust were assessed on a job-by-job basis by experienced experts. Analysis was performed by conditional logistic regression and presented in odds ratio (ORs) estimates and $95 \%$ confidence intervals (CI). Overall, a non significant relationship between occupational wood dust exposure and NPC risk for all subjects was observed (ORs=1.61, 95\% CI 0.99-2.59); however, the risk became significant when analyses focused on types 2 and 3 of NPC (ORs $=1.62,95 \% \mathrm{CI}$ 1.03-2.74). The significant association was stronger for those exposed to wood dust for $>10$ year $(\mathrm{ORs}=2.26,95 \% \mathrm{CI}$ 1.10-4.63), for those with first-time exposure at age $>25$ year $(\mathrm{ORs}=\mathbf{2 . 0 7}, 95 \% \mathrm{CI}$ 1.08-3.94), and for those who had a high cumulative exposure (ORs=2.17,95\% CI 1.03-4.58) when compared with those considered unexposed. In conclusion, wood dust is likely to be associated with an increased risk of type 2 or 3 NPC in the Thai population. The results of this study show that semi-quantitative exposure assessment is suitable for occupational exposure assessment in a case control study and complements the information from self-reporting.
\end{abstract}

Keywords: Occupational exposure - exposure assessment - wood dust - nasopharyngeal cancer

Asian Pac J Cancer Prev, 16 (10), 4339-4345

\section{Introduction}

Nasopharyngeal cancer (NPC) has a high incidence in some areas of the world, e.g. Southern China, Taiwan, South East Asia, North Africa and the Arctic (Parkin et al., 2002). In Thailand, data from international reports showed that the estimated age-standardized incidence rates were 4.5/100,000 in males and 1.6/100,000 in females; this is considered an intermediate incidence level compared with other regions of the world (Khuhaprema et al., 2007). The WHO classified NPC into three histologic types: keratinizing squamous cell carcinoma (type 1) and nonkeratinizing carcinoma, which is further characterized as differentiated (type 2) or undifferentiated (type 3). Type 3 NPC represents over $95 \%$ of NPC in high incidence areas. In contrast, type $1 \mathrm{NPC}$ is predominant in low incidence regions, and may have an etiology different from that of the other two histologic types (Vauhan et al.,1996).

Numerous environmental and genetic factors have been shown to be associated with the development of NPC. The strongest risk factor for NPC know today is infection of the Epstein-Bar virus (EBV) (Raab-Traub, 2002; Zheng et al., 1994). Consuming salted foods, especially, in the weaning years(Ward et al., 2000), smoking tobacco (Chen et al., 1990), and drinking alcohol (Chen et al., 2009) were also found associated with an increased risk of NPC. Other studies have inconsistently linked increased NPC risk with ENT Chronic diseases (Yuan et al., 2000; Zou et al., 2000).

Previous reports based on very few subjects and lacking controls for confounding factors indicated that

${ }^{1}$ Department of Preventive and Social Medicine, Faculty of Medicine, Srinakharinwirot University, ${ }^{2}$ Research Division, National Cancer Institute, ${ }^{3}$ Occupational and Environmental Medicine Center, Nopparat Rajthanee Hospital, Bangkok,Thailand, ${ }^{4}$ International Agency for Research on Cancer, Lyon, France, ${ }^{5}$ Centre for Public Health Research, Massey University, Wellington, New Zealand, ${ }^{6}$ Department of Industrial Hygiene and Safety, Faculty of Public Heath, Burapha University, Chonburi, ${ }^{7}$ School of Allied Health Science and Public Health, Walailak University, Nakhon Si Thammarat, ${ }^{8}$ Department of Safety Engineering, Faculty of Engineering, South-east Asia University Bangkok,Thailand, ${ }^{9}$ Tisch Cancer Institute, Icahn School of Medicine at Mount Sinai, New York, USA.

*For correspondence : sulee@health.moph.go.th 
NPC risk was associated with a wood-related occupations i.e. furniture and cabinet-making (IARC, 1987). This then led to occupational wood dust exposure as being one of the most highly suspected factors in the development of NPC. A subsequent cohort study revealed a significant increase in the standardized mortality ratio of exposed wood dust workers at 5.3 folds $(95 \% \mathrm{CI}=1.7-12.4, \mathrm{n}=5)$ (IARC, 1995). Some other cohort studies found very small numbers of cases at the end of the follow-up periods, which called into question whether wood-related workers were at an increased risk for NPC or not (Innos et al., 2000; Siew et al., 2012). Some case-control studies showed significant associations between wood dust exposure and NPC(Armstrong et al., 2000; Hildesheim et al., 2001); however, other studies found no associations(Vaughan, 2000). In 2011, an IARC monograph concluded that wood dust strongly caused cancer of nasal cavities and paranasal sinuses, but the association with NPC was weak, due to the limited numbers of studies, particularly, those specifying histological type (IARC, 2012).

In Thailand, located in Southeast Asia, 37\% of the land area is covered by tropical forests (Royal Forest Department, 2000), with wood being a major raw material for various industries. A large amount of wood dust is generated through these processes such as cutting, drilling, assembling and finishing. It is estimated that 226,060 Thai workers are routinely exposed to wood dust (Ekpanyaskul et al., 2008). Previous reports of risk factors for NPC in the Thai population showed an association between wood dust and NPC (Ekburanawat et al., 2010). However, those reports limited the exposure assessment to self-evaluation and may be subject to information bias. Exposure assessment still remains problematic in epidemiological investigations to identify the etiology of disease. Therefore, the objective of this study was to develop a semi-quantitative exposure assessment method and then utilize it to reevaluate the link between occupational exposure to wood dust and the development of NPC, and to examine variations in risk by histology. These results can serve a critical role in occupational cancer prevention and control, and this exposure assessment method could be used in other epidemiological studies to identify the causes of occupational cancer. Then, by controlling the working environment to reduce or eliminate cancer risks, this disease can be prevented.

\section{Materials and Methods}

\section{Study population}

This study is one part of the Thai NPC risk factor project, which was approved by the ethical review committee for research in human subjects at the National Cancer Institute, Thailand. The methodology has been described in elsewhere (Ekburanawat et al., 2010). In brief, the design of this project was a 1:1 matched casecontrol study conducted at the National Cancer Institute in Bangkok and 5 regional cancer centers. Cases were all new incident NPC patients, recruited at their first visit to the center and histologically diagnosed during the period of 2007-2009. Controls were randomly selected from healthy persons who visited non NPC patient admitted to the same center. 327 cases (participation rate 99.6\%) and 327 controls (participation rate $99.0 \%$ ) were recruited in the same study period matched by age, gender and center. The distribution of the 327 cases by major histological type was as follows: undifferentiated cell type or WHO type $3=237$ cases $(72.5 \%)$, non-keratinizing cell type or WHO type $2=79$ cases $(24.2 \%)$ and squamous cell type or WHO type 1 / unknown=11 cases $(3.3 \%)$.

\section{Data collection}

Informed consent was obtained from all participants. Face to face interviews were done by trained nurse interviewers. The same questionnaires were used for both groups without knowing the case-control status. Data of age, gender, address, race, religion, marital status, educational level, tobacco smoking, alcohol intake, betel nut chewing, salted fish consumption, family history of NPC in first degree relatives and complete detailed occupational histories were gathered via interviews. Blood tests for EBV latent infection were also done. The result of personal and behavioral risk factors was reported in a previous report (Ekburanawat et al., 2010). For all cases, diagnosis dates and pathological results were collected from treatment documents.

\section{Exposure assessment}

This study was utilized the semi-quantitative exposure assessment method. Participants were asked to report all occupations they had held for more than 1 year, for each occupation specifying; job titles, duration of work, name of the workplace, type and size of workplace, duties and job description, and daily activities and time for doing each activity. In addition, data were collected from each participant's workplace about the machines, tools, chemicals used, ventilation, personal protective equipment used, and self reported exposure.

Occupational histories in questionnaires of all participants were sent to evaluate potential exposure to wood dust on a job-by-job basis by 3 experts in Thailand who had previously conducted research in industrial hygiene or related fields (A.T., N.S. and T.R.). Questionnaires were reviewed and assessed without knowing the case-control status. All occupations were assessed for exposure to wood dust or not. If considered "exposed", an expert will assess three aspects of exposure: i) probability, ii) frequency and iii) intensity. The exposure assessment was conducted using the coder manual from the Epilymph study (Mannetje, 2001). Each index of exposure was presented in a three-step scale. The criteria for the (1) probability, (2) frequency, and (3) intensity of exposure were as follows, respectively: possible exposure, probable exposure, and definite exposure; low frequency with exposure $1-5 \%$ of working time, moderate frequency with exposure 6-30\% of working time, and high frequency with exposure $>30 \%$ of working time; and low intensity with exposure to $0.02-1 \mathrm{mg} / \mathrm{m}^{3}$ of total dust, moderate intensity with exposure to $>1-10 \mathrm{mg} / \mathrm{m}^{3}$ of total dust, and high intensity with exposure to $>10 \mathrm{mg} / \mathrm{m}^{3}$ of total dust. For participants who were exposed to wood dust in more than 1 occupation, the highest score for each aspect of exposure was used for analysis. The reliability of expert 
DOI:http://dx.doi.org/10.7314/APJCP.2015.16.10.4339 Semi-quantitative Exposure Assessment of Occupational Exposure to Wood Dust and Nasopharyngeal Cancer Risk

Table 1. The Association between Wood Dust Exposure Assessed by Expert and Risk of Nasopharyngeal Cancer

\begin{tabular}{|c|c|c|c|c|c|c|c|c|}
\hline \multirow[t]{2}{*}{ Exposure } & \multicolumn{4}{|c|}{ All subject $=654$} & \multicolumn{4}{|c|}{ WHO type $2 \& 3=632$} \\
\hline & $\begin{array}{l}\text { Case } \\
\mathrm{n}(\%)\end{array}$ & $\begin{array}{c}\text { Control } \\
\mathrm{n}(\%)\end{array}$ & $\begin{array}{l}\text { Crude ORs } \\
(95 \% \mathrm{CI})\end{array}$ & $\begin{array}{l}\text { Adjusted ORs }{ }^{\mathrm{a}} \\
(95 \% \mathrm{CI})\end{array}$ & $\begin{array}{l}\text { Case } \\
\mathrm{n}(\%)\end{array}$ & $\begin{array}{c}\text { Control } \\
\mathrm{n}(\%)\end{array}$ & $\begin{array}{c}\text { Crude ORs A } \\
(95 \% \mathrm{CI})\end{array}$ & $\begin{array}{l}\text { Adjusted ORs }{ }^{\mathrm{a}} \\
\qquad(95 \% \mathrm{CI})\end{array}$ \\
\hline \multicolumn{9}{|l|}{ Self-reported } \\
\hline No & $\begin{array}{c}265 \\
(81.0)\end{array}$ & $\begin{array}{c}290 \\
(88.7)\end{array}$ & 1.00 & 1.00 & $\begin{array}{c}257 \\
(81.3)\end{array}$ & $\begin{array}{c}282 \\
(89.2)\end{array}$ & 1.00 & 1.00 \\
\hline Yes & $\begin{array}{c}62 \\
(19.0)\end{array}$ & $\begin{array}{c}37 \\
(11.3)\end{array}$ & $\begin{array}{c}1.83 \\
(1.18-2.86)\end{array}$ & $\begin{array}{c}1.61 \\
(0.99-2.59)\end{array}$ & $\begin{array}{c}59 \\
(18.7)\end{array}$ & $\begin{array}{c}34 \\
(10.8)\end{array}$ & $\begin{array}{c}1.86 \\
(1.17-2.94)\end{array}$ & $\begin{array}{c}1.68 \\
(1.03-2.74)\end{array}$ \\
\hline \multicolumn{9}{|l|}{ Duration of exposure } \\
\hline None & $\begin{array}{c}265 \\
(81.0)\end{array}$ & $\begin{array}{c}290 \\
(88.7)\end{array}$ & 1.00 & 1.00 & $\begin{array}{c}257 \\
(81.3)\end{array}$ & $\begin{array}{c}282 \\
(89.2)\end{array}$ & 1.00 & 1.00 \\
\hline Exposed $<10$ years & $\begin{array}{c}27 \\
(8.3)\end{array}$ & $\begin{array}{c}19 \\
(5.8)\end{array}$ & $\begin{array}{c}1.50 \\
(0.82-2.74)\end{array}$ & $\begin{array}{c}1.33 \\
(0.70-2.53)\end{array}$ & $\begin{array}{c}26 \\
(8.2)\end{array}$ & $\begin{array}{l}19 \\
(6.0)\end{array}$ & $\begin{array}{c}1.45 \\
(0.79-2.67)\end{array}$ & $\begin{array}{c}1.30 \\
(0.68-2.49)\end{array}$ \\
\hline Exposed $\geq 10$ years & $\begin{array}{c}35 \\
(10.7)\end{array}$ & $\begin{array}{c}18 \\
(5.5)\end{array}$ & $\begin{array}{c}2.26 \\
(1.20-4.25)\end{array}$ & $\begin{array}{c}1.98 \\
(1.01-3.89)\end{array}$ & $\begin{array}{c}33 \\
(10.5)\end{array}$ & $\begin{array}{c}15 \\
(4.8)\end{array}$ & $\begin{array}{c}2.46 \\
(1.26-4.84)\end{array}$ & $\begin{array}{c}2.26 \\
(1.10-4.63)\end{array}$ \\
\hline \multicolumn{9}{|l|}{ Age start exposure } \\
\hline None & $\begin{array}{c}265 \\
(81.0)\end{array}$ & $\begin{array}{c}290 \\
(88.7)\end{array}$ & 1.00 & 1.00 & $\begin{array}{c}257 \\
(81.3)\end{array}$ & $\begin{array}{c}282 \\
(89.2)\end{array}$ & 1.00 & 1.00 \\
\hline$<25$ years & $\begin{array}{c}26 \\
(8.0)\end{array}$ & $\begin{array}{c}20 \\
(6.1)\end{array}$ & $\begin{array}{c}1.44 \\
(0.77-2.68)\end{array}$ & $\begin{array}{c}1.29 \\
(0.67-2.51)\end{array}$ & $\begin{array}{c}22 \\
(7.3)\end{array}$ & $\begin{array}{c}19 \\
(6.0)\end{array}$ & $\begin{array}{c}1.41 \\
(0.74-2.68)\end{array}$ & $\begin{array}{c}1.31 \\
(0.66-2.60)\end{array}$ \\
\hline$\geq 25$ years & $\begin{array}{c}36 \\
(11.0)\end{array}$ & $\begin{array}{c}17 \\
(5.2)\end{array}$ & $\begin{array}{c}2.26 \\
(1.24-4.09)\end{array}$ & $\begin{array}{c}1.94 \\
(1.03-3.65)\end{array}$ & $\begin{array}{c}36 \\
(11.4)\end{array}$ & $\begin{array}{c}15 \\
(4.8)\end{array}$ & $\begin{array}{c}2.34 \\
(1.27-4.30)\end{array}$ & $\begin{array}{c}2.07 \\
(1.08-3.94)\end{array}$ \\
\hline \multicolumn{9}{|l|}{ Latency } \\
\hline None & $\begin{array}{c}265 \\
(81.0)\end{array}$ & $\begin{array}{c}290 \\
(88.7)\end{array}$ & 1.00 & 1.00 & $\begin{array}{c}257 \\
(81.3)\end{array}$ & $\begin{array}{c}282 \\
(89.2)\end{array}$ & 1.00 & 1.00 \\
\hline Exposed $<10$ years & $\begin{array}{c}10 \\
(3.1)\end{array}$ & $\begin{array}{c}5 \\
(1.5)\end{array}$ & $\begin{array}{c}2.00 \\
(0.68-5.85)\end{array}$ & $\begin{array}{c}1.55 \\
(0.51-4.75)\end{array}$ & $\begin{array}{c}10 \\
(3.2)\end{array}$ & $\begin{array}{c}5 \\
(1.6)\end{array}$ & $\begin{array}{c}2.00 \\
(0.68-5.85)\end{array}$ & $\begin{array}{c}1.56 \\
(0.51-4.79)\end{array}$ \\
\hline Exposed $\geq 10$ years & $\begin{array}{c}52 \\
(15.9)\end{array}$ & $\begin{array}{c}32 \\
(9.8)\end{array}$ & $\begin{array}{c}1.8 \\
(1.10-2.94)\end{array}$ & $\begin{array}{c}1.62 \\
(0.96-2.75)\end{array}$ & $\begin{array}{c}49 \\
(15.5)\end{array}$ & $\begin{array}{c}29 \\
(9.2)\end{array}$ & $\begin{array}{c}1.83 \\
(1.10-3.04)\end{array}$ & $\begin{array}{c}1.71 \\
(0.99-2.96)\end{array}$ \\
\hline \multicolumn{9}{|l|}{ Probability of exposure } \\
\hline None & $\begin{array}{c}265 \\
(81.0)\end{array}$ & $\begin{array}{c}290 \\
(88.7)\end{array}$ & 1.00 & 1.00 & $\begin{array}{c}257 \\
(81.3)\end{array}$ & $\begin{array}{c}282 \\
(89.2)\end{array}$ & 1.00 & 1.00 \\
\hline Possible (score 1) & $\begin{array}{c}1 \\
(0.3)\end{array}$ & $\begin{array}{c}4 \\
(1.2)\end{array}$ & - & - & $\begin{array}{c}1 \\
(0.3)\end{array}$ & $\begin{array}{c}4 \\
(1.3)\end{array}$ & - & - \\
\hline Probable (score 2) & $\begin{array}{l}10 \\
(3.1)\end{array}$ & $\begin{array}{c}5 \\
(1.5)\end{array}$ & $\begin{array}{c}2.21 \\
(0.75-6.54)\end{array}$ & $\begin{array}{c}1.78 \\
(0.57-5.59)\end{array}$ & $\begin{array}{c}9 \\
(2.9)\end{array}$ & $\begin{array}{c}5 \\
(1.6)\end{array}$ & $\begin{array}{c}2.01 \\
(0.67-6.09)\end{array}$ & $\begin{array}{c}1.71 \\
(0.54-5.47)\end{array}$ \\
\hline Definite (score 3) & $\begin{array}{c}51 \\
(15.6)\end{array}$ & $\begin{array}{c}28 \\
(8.6)\end{array}$ & $\begin{array}{c}2.01 \\
(1.22-3.29)\end{array}$ & $\begin{array}{c}1.76 \\
(1.04-2.98)\end{array}$ & $\begin{array}{c}49 \\
(15.5)\end{array}$ & $\begin{array}{c}25 \\
(7.9)\end{array}$ & $\begin{array}{c}2.09 \\
(1.25-3.49)\end{array}$ & $\begin{array}{c}1.88 \\
(1.10-3.24)\end{array}$ \\
\hline \multicolumn{9}{|l|}{ Frequency of exposure } \\
\hline None & $\begin{array}{c}265 \\
(81.0)\end{array}$ & $\begin{array}{c}290 \\
(88.7)\end{array}$ & 1.00 & 1.00 & $\begin{array}{c}257 \\
(81.3)\end{array}$ & $\begin{array}{c}282 \\
(89.2)\end{array}$ & 1.00 & 1.00 \\
\hline Low (score 1 ) & $\begin{array}{c}11 \\
(3.4)\end{array}$ & $\begin{array}{c}11 \\
(3.4)\end{array}$ & $\begin{array}{c}1.12 \\
(0.46-2.74)\end{array}$ & $\begin{array}{c}0.99 \\
(0.40-2.53)\end{array}$ & $\begin{array}{c}11 \\
(3.5)\end{array}$ & $\begin{array}{c}11 \\
(3.5)\end{array}$ & $\begin{array}{c}1.13 \\
(0.46-2.75)\end{array}$ & $\begin{array}{c}1.01 \\
(0.40-2.54)\end{array}$ \\
\hline Moderate (score 2) & $\begin{array}{c}27 \\
(8.3)\end{array}$ & $\begin{array}{c}10 \\
(3.1)\end{array}$ & $\begin{array}{c}2.94 \\
(1.38-6.28)\end{array}$ & $\begin{array}{c}2.73 \\
(1.20-6.23)\end{array}$ & $\begin{array}{c}25 \\
(7.9)\end{array}$ & $\begin{array}{c}8 \\
(2.5)\end{array}$ & $\begin{array}{c}3.06 \\
(1.37-6.82)\end{array}$ & $\begin{array}{c}3.02 \\
(1.27-7.19)\end{array}$ \\
\hline High (score 3) & $\begin{array}{c}24 \\
(7.3)\end{array}$ & $\begin{array}{c}16 \\
(4.8)\end{array}$ & $\begin{array}{c}1.56 \\
(0.82-2.95)\end{array}$ & $\begin{array}{c}1.36 \\
(0.69-2.66)\end{array}$ & $\begin{array}{c}23 \\
(7.3)\end{array}$ & $\begin{array}{c}15 \\
(4.8)\end{array}$ & $\begin{array}{c}1.60 \\
(0.83-3.08)\end{array}$ & $\begin{array}{c}1.42 \\
(0.71-2.83)\end{array}$ \\
\hline \multicolumn{9}{|l|}{ Intensity of exposure } \\
\hline None & $\begin{array}{l}265 \\
(81)\end{array}$ & $\begin{array}{c}290 \\
(88.7)\end{array}$ & 1.00 & 1.00 & $\begin{array}{c}257 \\
(81.3)\end{array}$ & $\begin{array}{c}282 \\
(89.2)\end{array}$ & 1.00 & 1.00 \\
\hline Low (score 1) & $\begin{array}{c}29 \\
(8.9)\end{array}$ & $\begin{array}{c}14 \\
(4.3)\end{array}$ & $\begin{array}{c}2.36 \\
(1.19-4.67)\end{array}$ & $\begin{array}{c}2.12 \\
(1.02-4.40)\end{array}$ & $\begin{array}{c}27 \\
(8.6)\end{array}$ & $\begin{array}{c}14 \\
(4.5)\end{array}$ & $\begin{array}{c}2.21 \\
(1.10-4.41)\end{array}$ & $\begin{array}{c}2.09 \\
(0.99-4.37)\end{array}$ \\
\hline Moderate (score 2) & $\begin{array}{c}31 \\
(9.5)\end{array}$ & $\begin{array}{c}22 \\
(6.7)\end{array}$ & $\begin{array}{c}1.53 \\
(0.87-2.69)\end{array}$ & $\begin{array}{c}1.34 \\
(0.74-2.45)\end{array}$ & $\begin{array}{c}30 \\
(9.5)\end{array}$ & $\begin{array}{c}19 \\
(6.0)\end{array}$ & $\begin{array}{c}1.63 \\
(0.91-2.93)\end{array}$ & $\begin{array}{c}1.45 \\
(0.78-2.69)\end{array}$ \\
\hline High (score 3) & $\begin{array}{c}2 \\
(0.6)\end{array}$ & $\begin{array}{c}1 \\
(0.3)\end{array}$ & $\begin{array}{c}2.00 \\
(0.18-22.06)\end{array}$ & $\begin{array}{c}1.53 \\
(0.12-18.93)\end{array}$ & $\begin{array}{c}2 \\
(0.6)\end{array}$ & $\begin{array}{c}1 \\
(0.3)\end{array}$ & $\begin{array}{c}2.00 \\
(0.18-22.06)\end{array}$ & $\begin{array}{c}1.61 \\
(0.13-20.14)\end{array}$ \\
\hline \multicolumn{9}{|l|}{ Cumulative exposure $^{\mathrm{b}}$} \\
\hline None & $\begin{array}{l}265 \\
(81)\end{array}$ & $\begin{array}{c}290 \\
(88.7)\end{array}$ & 1.00 & 1.00 & $\begin{array}{c}257 \\
(81.3)\end{array}$ & $\begin{array}{c}282 \\
(89.2)\end{array}$ & 1.00 & 1.00 \\
\hline$<70$ & $\begin{array}{c}30 \\
(9.2)\end{array}$ & $\begin{array}{c}20 \\
(8.1)\end{array}$ & $\begin{array}{c}1.58 \\
(0.88-2.82)\end{array}$ & $\begin{array}{c}1.42 \\
(0.76-2.64)\end{array}$ & $\begin{array}{c}28 \\
(8.9)\end{array}$ & $\begin{array}{c}20 \\
(6.3)\end{array}$ & $\begin{array}{c}1.53 \\
(0.85-2.75)\end{array}$ & $\begin{array}{c}1.39 \\
(0.75-2.60)\end{array}$ \\
\hline$\geq 70$ & $\begin{array}{c}32 \\
(9.8)\end{array}$ & $\begin{array}{c}17 \\
(5.2)\end{array}$ & $\begin{array}{c}2.21 \\
(1.14-4.27)\end{array}$ & $\begin{array}{c}1.89 \\
(0.94-3.81)\end{array}$ & $\begin{array}{c}31 \\
(9.8)\end{array}$ & $\begin{array}{c}14 \\
(4.5)\end{array}$ & $\begin{array}{c}2.42 \\
(1.20-4.91)\end{array}$ & $\begin{array}{c}2.17 \\
(1.03-4.58)\end{array}$ \\
\hline
\end{tabular}

${ }^{* a}$ Adjusted for educational level, smoking status, and alcohol intake; ${ }^{\mathrm{b}}$ Defined as intensity $\mathrm{X}$ duration (year 
Chatchai Ekpanyaskul et al

assessment in each dimension was as follows: confidence intraclass correlation $(\mathrm{ICC})=0.79(95 \% \mathrm{CI}=0.77-0.81)$, frequency $\mathrm{ICC}=0.71(95 \% \mathrm{CI}=0.69-0.73)$, and intensity $\mathrm{ICC}=0.76$ (95\%CI $=0.74-0.78)$. Finally, the three experts discussed and scored each job by consensus of the group. The results of the expert assessment were used to analyze the association between wood dust and NPC.

\section{Statistical analyses}

All statistical analysis in this study was performed with SPSS, version 21.0(IBM/SPSS Inc). The descriptive data were presented with the number, percentage, and ratio for categorical data, and the mean with standard deviation for continuous data. The difference between the characteristics of the cases and controls was assessed by a chi-square test or Fisher's exact test. The level of statistical significance is $p$-value $<0.05$. All occupations were grouped and coded according to the International Standard Classification of Occupations, using the revised edition of 1968 (ISCO 1968). The association between wood dust exposure and NPC was assessed by conditional logistic regression for crude odds ratio (ORs) and then adjusted for confounders. $95 \%$ confidence intervals $(95 \% \mathrm{CI})$ were used to determine statistical significance(Chan, 2005). Because $>90 \%$ of the cases were seropositive for antiEBV antibodies measured, and EBV is considered by many to be a necessary risk factor for the development of NPC (Jia et al., 2012), the effect EBV seropositivity on risks associated with occupational exposure was not included in the model. Finally, this study was selected educational level, smoking status, and alcohol intake adjust in the final model for regression analysis.

\section{Results}

The mean age of the cases was $48.3 \pm 12.7$ years while the mean age of the controls was $47.9 \pm 12.5$ years. The ratio of male to female was 3:1. More than $90 \%$ of the case and control participants were Buddhists of Thai ethnicity. Three-fourths of both case and control participants were married. Participants in cases $(86.5 \%)$ had statistically significant higher education than in the control $(70.3 \%)$ with $p$ value $<0.001 .37 .9 \%$ of case and $26.0 \%$ of control participants were current smokers. $25.1 \%$ of the case and $19.0 \%$ of the control participants were ex-smokers. More than $50 \%$ of the subjects had a history of alcohol intake. $35.5 \%$ of the case and $42.5 \%$ of the control participants were current alcohol drinkers. $25.1 \%$ of the case and $12.8 \%$ of control participants had stopped drinking. Both the proportion of smoke exposure and alcohol intake were statistically different between the case and the control groups ( $\mathrm{p}$ value $<0.001$ ) while other factors were not statistically different.

Occupational data were available for all cases and controls. In all, 654 subjects (327 cases and 327 controls) reported for total of 1,216 occupations (647 occupations from cases and 569 occupations from controls). The average number of jobs was 1.86 per participant ( 1.98 per case and 1.74 per control). Of these, 108 jobs ( $8.9 \%$ of total jobs) from 99 subjects ( $15.1 \%$ of total subjects) were assessed by experts as having been exposed to wood dust.
The top three wood related occupations as classified by the ISCO 1968 in case and control group who expert evaluate as wood dust exposure were carpenter $(21.9 \%$ / 22.7\%), construction worker $(18.8 \% / 18.2 \%)$, and cabinetmaker $(15.6 \% / 9.1 \%)$, respectively.

The association between occupational exposure to wood dust and NPC as presented by the adjusted odds ratios are shows in table 1. Participants who were "ever exposed" to wood dust were not at increased risk for NPC (ORs $=1.61,95 \%$ CI 0.99-2.59), , but it was relevant types 2 and 3 NPC (ORs $=1.68,95 \%$ CI 1.03-2.74). The significant association was stronger for those exposed to wood dust for $\geq 10$ years (ORs $=2.26,95 \%$ CI 1.10-4.63). Participants who were first exposed to wood dust at early age ( $<25$ years) show no significant association, but firsttime exposure at age 25 years or older showed a significant association with type 2 and 3 NPC (ORs $=2.07$, 95\%CI 1.08-3.94), as well as for all subjects (ORs $=1.94,95 \% \mathrm{CI}$ 1.03-3.65). A latency of exposure for more than 10 years also shows a non-significant association with an increased risk of type 2 and 3 NPC (ORs=1.71, 95\%CI 0.99-2.96). The assessment of probability of exposure shows results of significant association in definite probability groups (ORs $=1.88,95 \%$ CI 1.10-3.24). The frequency aspect shows a significant association in moderate frequency, exposed $6-30 \%$ of working time with ORs $=3.02(95 \% \mathrm{CI}$ 1.27-7.19) for type 2 and $3 \mathrm{NPC}$ and ORs $=2.73(95 \% \mathrm{CI}$ 1.20-6.23) for all subjects. There was no association of an increased risk of NPC in high and moderate intensity of exposure groups, but there were only 2 cases and 1 control in the high intensity of exposure group. Individuals with more than the median of cumulative exposure ( $\geq 70$ intense years of exposure) had a ORs of 2.17(95\%CI 1.03-4.53) compared to unexposed people.

\section{Discussion}

Dust particles from wood occur frequently in the Thai occupational environment, and the number of wood-processing industries has been increasing over the past decade due to socioeconomic growth. Controversy exists over whether or not occupational exposure to wood dust increases risk for respiratory cancers. There are a few studies in Asian countries regarding the risk of NPC by wood dust exposure, where the majority of raw material and wood product are come from hard wood. Presently, workers' compensation in Thailand considers wood dust related cancer as an occupational cancer; in other words, workers should be compensated monetarily (Ekpanyaskul et al., 2008). The objective in this study was to develop an expert a semi-quantitative exposure assessment method that could be used to reevaluate the link between the occupational exposure to wood dust and the development of NPC, and to examine variations in risk by histological type. In this study, complete occupational histories were obtained by trained interviewers and exposure assessments were carried out by 3 experts. The study found quite different risk factor profiles for NPC by histological type. Potential occupational exposure to wood dust was associated with the risk of nonkeratinizing and undifferentated carcinoma (ORs=1.68,95\%CI 1.03-2.74), 
but it seems unrelated with keratinizing squamous cell carcinoma. The result is consistent with those from a casecontrol study conducted in Taiwan in which most cases were diagnosed as nonkertanizing and undifferentiated carcinomas (Hildesheim et al., 2001; Yang et al., 2005). They also found that individuals who had a long duration of exposure ( $\geq 10$ years) or had first been exposed to wood dust before the age of 25 years had a higher risk of NPC compared with the unexposed group. In our study, a significantly increased risk of types 2 and 3 NPC for those exposed $\geq 10$ years was found (ORs $=2.26,95 \% \mathrm{CI}$ 1.10-4.63); however, an increased risk was observed among those who had first been exposed to wood dust after the age of 25 years (ORs 2.07, 95\%CI 1.08-3.94). (ORs $=2.10,95 \%$ CI 1.10-4.00). These results support the hypothesis NPC may be related to the occupational exposure of wood dust.

A basic hypothesis is that high intensity exposure to wood dust is believed to represent a key aspect of wood dust carcinogenesis. In our study, surprisingly, this high intensity of exposure was not associated with NPC risk. The inconsistent results may be due to the small numbers of subjects in this group. However, we did find an increased risk among people with cumulative exposure of $\geq 70$ intensity-years. Similarly, the results from the previous study in Taiwan found that risks were highest in the high intensity (multiply with duration) type of exposure (Hildesheim et al., 2001).

Currently, the mechanism of wood dust and NPC is still not clear. Most discussion on carcinogenesis was focused on inflammation process. (IARC, 2012). The nasopharynx could trap dust particles in the inspired air, then, causing to mechanical irritation, inflammation, which increased cell proliferation and transformation in respiratory tract system. (Liorente et al., 2008). Other mechanisms also have been proposed such as repairing of sublethal damage and inducing apoptosis (Cui et al., 2012) or interleukin-18 promoter $-607 \mathrm{C}>\mathrm{A}$ polymorphism contributes to nasopharyngeal carcinoma risk: evidence from a meta-analysis including 1,886 subjects (Guo and Xia, 2013). The type of wood dust (soft wood or hard wood) was considered to be one of the factors related to wood dust carcinogenesis (IARC, 2012). The literature review in the exposure assessment suggests that experts are influenced by some of the same factors as subjects, that is, sensory perceptions affect judgment, and estimates are easier for board class of hazards like wood dust than for a specific type of wood. The role of the type of wood dust is still controversial in epidemiological studies. In the present study as well as many others, the data of occupational histories come only from an interview, with most of the participants unable to identify the type of wood dust to which they were exposed. In Thailand, for the past 20 years, the major type of wood found in forests and used in industry has been primarily hard woods such as teak and rosewood. Nevertheless, exposure to soft wood dust cannot be ruled out. Chemical substances in wood or wood preservatives that frequently appear with wood dust such as formaldehyde, chlorophenols, potassium dichromate, fungus toxins and (1-->3)-beta-D-glucans still remain unclear as well. The recent synthesis data by the IARC working group would likely be inversely associated with these agents as well (IARC, 2012).

Underreporting occupational cancer is still problematic in many countries. In case-control studies suitable to identify its association, the problem remains of exposure assessment case control study. Due to the lack of any kind of exposure database, self-reports and semi-quantitative assessment by expert estimates of exposure are frequently used to measure exposure levels as the basis of an evaluation. The results obtained by self-reporting from individuals also showed that exposure to wood dust was associated with an increased risk of NPC. The quality of the information of self-reported exposure indicates that, although subjects can reliably and accurately report exposure under certain circumstances, it is also possible for subjects to provide exposure data of such low quality that exposure effect relations will be observed or even reversed in direction. Semi-quantitative exposure assessment by expert assessment is a strategy that can optimize the exposure estimation method. The evidence to date on expert assessment supports the belief that experts are better able to estimate exposure than study subjects (Yang et al., 2005). This use of this method has been increasing by experts such as industrial hygienists to infer exposure from job histories or estimate it based on a review of all subject's reported information. However, this method still has some handicap. Experts may not be familiar with certain jobs, industries, or the conditions present in the worksite or estimated depend on detail on subject reported. The limitations of expert assessment are still the critical factors in understanding the exposure, not intimate knowledge of the work activity. Factors related to exposure that are easy to answer such as task and raw material also increase the detail and accuracy of experts' exposure estimate. Asking about the health problems of a subject or colleague enhances the expert's recall and makes it easier to make an exposure estimate. The number of experts also matters. Using two or more experts to find a consensus regarding wood dust exposure increases the validity of the measurement.

Several limitations should be considered in interpreting these results. First, exposure assessments to wood dust in this study were based on the professional judgment of experts. No actual measurement of wood dust was done. Therefore a tendency to misclassify the exposure still remains. In this study, our experts assessed exposure without knowing the case-control status and other relevant data of participants, except for occupational histories. For avoided the short-term exposure, the study was conducted over the longer-term exposure, at least one year. Therefore, if an exposure misclassification occurred it tended to be a non-differential misclassification instead of a differential misclassification. Because non-differential misclassifications will more likely lead to a hypothesis summary toward the null than rather than away from the null(Delgado-Rodriguez and Llorca, 2004), the association of wood dust exposure and NPC found in this study was less likely to come from an exposure misclassification bias. By means of this research design limitation, we showed that our visiting controls were not significantly different from the cases in many general conditions such 
as age, gender, race, religion, marital status and center visited. The results of matching with age and gender make the controls more likely to be similar to cases. For occupational data, our controls served to randomly recruit cancer centers visitors who were likely to be working persons more than unemployed care-givers. The proportion of lifetime unemployed participants in the control $(3.1 \%)$ was nearly comparable with the cases $(3.4 \%)$. For all of these reasons, the controls in this study were suitable enough to be compared with the cases.

The strengths of this study are the large number of cases and controls, and that fact that complete and detailed occupational histories were collected from 654 subjects with a response rate of $>99 \%$. Newly diagnosed cases were used to minimize recall bias. The determinant of exposure in this study was superior to the previous report method. The questionnaire of this study was constructed from previous occupational cancer epidemiological studies to guide the formulation of questions and interpretation of responses leading to the identification of determinants of exposure and improving the validity of exposure-level. These data were also calculated for intensity, frequency, and duration of wood dust exposure based on occupational history data, which had more information than previous reports. Assessments by experts almost always rely on self reports as the starting point, utilizing subject exposure reports to gather information on work tasks and conditions. The result of the semi-quantitative exposure assessment by expert assessment method confirms the association between wood dust and NPC, but had more information and found a higher strength of association than the selfreport method.

In conclusion, the semi-quantitative exposure assessment by expert assessment is a suitable way to occupational exposure assessment in case-control studies. The improved performance and techniques in the questionnaire such as factors related to exposure and indentifying determinant of exposure are useful. This study reveals that occupational exposure to wood dust is likely to be associated with an increased risk of NPC. A high score of cumulative exposure was also shown to present a significantly increased risk. These results support the hypothesis that wood dust may increase risk factors of NPC among the Thai population, where the major histologic types are nonkeratinizing and undifferentiated carcinoma. However, assessing the chemical properties and the plausible effects of the complex exposure at work are needed to further understand carcinogenesis as the result of exposure to wood dust. Routine hygiene measurements and improving the exposure database are useful to further identify the etiology of cancer.

\section{Acknowledgements}

This work was supported by the Faculty of Medicine, Srinakharinwirot University and the Thai National Cancer Institute. The authors declared no conflicts of interest and would like to thanks to IARC for technical support.

\section{References}

Armstrong RW, Imrey PB, Lye MS, Armstrong MJ, Yu MC, Sani
S (2000). Nasopharyngeal carcinoma in Malaysian Chinese: occupational exposures to particles, formaldehyde and heat. Int J Epidemiol, 29, 991-8.

Chan YH (2005). Biostatistics 305: Multinomial logistic regression analysis. Singapore Med J, 46, 259-68.

Chen CJ, Liang KY, Chang YS, et al (1990). Multiple risk factors of nasopharyngeal carcinoma: Epstein-Barr virus, malarial infection, cigarette smoking and familial tendency. Anticancer Res, 10, 547-53.

Chen L, Gallicchio L, Boyd-Lindsley K, et al (2009). Alcohol consumption and the risk of nasopharyngeal carcinoma: a systematic review. Nutr Cancer, 61, 1-15.

Cui YH, Liang HJ, Zhang QQ, et al (2012). Radiosensitivity enhancement by arsenic trioxide in conjunction with hyperthermia in the EC-1 esophageal carcinoma cell line. Asian Pac J Cancer Prev, 13, 1693-97.

Delgado-Rodriguez M, Llorca J (2004). Bias. J Epidemiol Community Health, 58, 635-41.

Ekburanawat W, Ekpanyaskul C, Brennan P, et al (2010). Evaluation of non-viral risk factors for nasopharyngeal carcinoma in Thailand: results from a case-control study. Asian Pac J Cancer Prev, 11, 929-32.

Ekpanyaskul C, Sangrajrang S, Padungtod C, et al (2008). Guideline for criteria diagnosis of occupational cancer, Santisiri press, Bangkok.

Guo XG and Xia Y. (2013). The Interleukin-18 promoter $-607 \mathrm{C}>$ A polymorphism contributes to nasopharyngeal carcinoma risk: evidence from a meta-analysis including 1,886 subjects. Asian Pac J Cancer Prev, 14, 7577-81.

Hildesheim A, Dosemeci M, Chan CC, et al (2001). Occupational exposure to wood, formaldehyde, and solvents and risk of nasopharyngeal carcinoma. Cancer Epidemiol Biomarkers Prev, 10, 1145-53.

IARC (1987). Overall evaluations of carcinogenicity: an updating of IARC Monographs volumes 1 to 42. IARC Monogr Eval Carcinog Risks Hum, 7, 1-440.

IARC (1995). Wood dust and formaldehyde. IARC Monogr Eval Carcinog Risks Hum, 62, 1-405.

IARC (2012). A Review of Human Carcinogens: Arsenic, Metals, Fibres, and Dusts. IARC Monogr Eval Carcinog Risks Hum, 100, 11-465.

Innos K, Rahu M, Rahu K, Lang I, Leon DA (2000). Wood dust exposure and cancer incidence: a retrospective cohort study of furniture workers in Estonia. Am J Ind Med, 37, 501-11.

Jia WH, Qin HD (2012). Non-viral environmental risk factors for nasopharyngeal carcinoma: a systematic review. Semin Cancer Biol, 22, 117-26.

Khuhaprema T, Srivatanakul P, Sriplung H, Wiangnon S, Sumitsawan Y, Attasara P(2007). Cancer in Thailand volume VI 2004-2006. Bangkok medical publisher, Bangkok.

Llorente JL,Núñez F, Rodrigo JP,et al (2008). Sinonasal adenocarcinomas: our experience. Acta Otorrinolaringol Esp, 59, 235-8.

Mannetje A(2001). The Epilymph study coders manual (version June 2001). IARC, Lyon.

Parkin DM, Whelan SL, Ferlay J, Teppo L, Thomas DB (2002). Cancer incidence in five continents volume VIII. IARC, Lyon.

Raab-Traub N (2002). Epstein-Barr virus in the pathogenesis of NPC. Semin Cancer Biol, 12, 431-41.

Royal Forest Department (2000), Forestry statistics of Thailand. ministry of natural resources and environment, Bangkok.

Siew ST, Kauppinen T, Kyyrönen P, Heikkilä P, Pukkala E(2012). Occupational exposure to wood dust and formaldehyde and risk of nasal, nasopharyngeal, and lung cancer among Finnish men. Cancer Management and Research, 4, 223-32

Teschke K, Olshan AF, Daniels JL, et al(2002). Occupational 

exposure assessment in case-control studies: opportunities for improvement. Occup Environ Med, 59, 575-93.

Vaughan T, Shapiro JA, Burt RD,et al (1996). Nasopharyngeal cancer in a low-risk population: defining risk factors by histological type. Cancer Epidemiol Biomarkers Prev, 5, 587-93.

Vaughan TL, Stewart PA, Teschke K(2000). Occupational exposure to formaldehyde and wood dust and nasopharyngeal carcinoma. Occup Environ Med, 57, 376-84.

Ward MH, Pan WH, Cheng YJ, et al (2000). Dietary exposure to nitrite and nitrosamines and risk of nasopharyngeal carcinoma in Taiwan. Int J Cancer, 86, 603-9.

Yang XR, Diehl S, Pfeiffer R,et al(2005). Evaluation of risk factors for nasopharyngeal carcinoma in high-risk nasopharyngeal carcinoma families in Taiwan. Cancer Epidemiol Biomarkers Prev, 14, 900-5.

Yuan JM, Wang XL, Xiang YB, et al(2000). Non-dietary risk factors for nasopharyngeal carcinoma in Shanghai, China. Int J Cancer, 85, 364-9.

Zheng X, Yan L, Nilsson B, Eklund G, Drettner B(1994). Epstein-Barr virus infection, salted fish and nasopharyngeal carcinoma. A case-control study in southern China. Acta Oncol, 33, 867-72.

Zou J, Sun Q, Akiba S, et al (2000). A case-control study of nasopharyngeal carcinoma in the high background radiation areas of Yangjiang, China. J Radiat Res, 41, 53-62. 